\section{Powtórzenia i przynależności. Poezja Eugeniusza Tkaczyszyna-Dyckiego wobec pamięci}

Justyna Tabaszewska

TEKSTY DRUGIE 2017, NR 2, S. 399-417
Badania zostały

sfinansowane ze środków

Narodowego Centrum

Nauki przyznanych

w ramach finansowania stażu po uzyskaniu stopnia naukowego doktora na podstawie decyzji numer DEC-2014/12/S/HS2/00079.

DOI: $10.18318 /$ td.2017.2.22

Istotą poezji jest nie tyle zasadność Co bezzasadność napomknień i powtórzeń1

\section{Uwagi wstępne}

Próbując określić lub zdefiniować współczesną literaturę, a poezję zwłaszcza, stajemy zawsze przed pokusą szukania w niej tego, co nowe, oryginalne, co odróżnia ją od wszystkiego, co powstawało wcześniej. O sile i zarazem nieuchronnej złudności takiej pokusy wiadomo już od dawna, zaświadczają o niej także - w przypadku polskiej literatury współczesnej - liczne wypowiedzi krytyków i badaczy działających w latach '9o XX wieku². Próbą

1 E. Tkaczyszyn-Dycki Piosenka o zależnościach i uzależnieniach, Biuro Literackie, Wrocław 2009, s. 13.

Por. P. Czapliński Ślady przełomu, Wydawnictwo Literackie, Kraków 1997; Codzienne, przedmiotowe, cielesne. Języki nowej wrażliwości w literaturze polskiej XX wieku, red. H. Gosk, Świat Literacki, Warszawa 2002; Polska proza i poezja po 1989 roku wobec tradycji, red. A. Główczewski, M. Wróblewski, Wydawnictwo UMK, Toruń 2007. Por. także E. Balcerzan Tradycja pogromców tradycji, "Teksty: teoria literatury, krytyka, interpretacja" 1979 nr 1.
Justyna

Tabaszewska

- doktor nauk

humanistycznych,

autorka książek/edna przyroda czy przyrody alternatywne? O pojmowaniu i obrazach przyrody w polskiej poezji i Poetyki pamięci.Współczesna poezja wobec tradycji i pamięci oraz artykułów publikowanych m.in. $w_{\text {"Tekstach Drugich" }}$ i „Przeglądzie Kulturoznawczym". Aktualnie pracuje w Instytucie Badań Literackich nad projektem „Afektywne poetyki pamięci. Polska literatura i kultura wobec przełomu roku 1989". Kontakt: justyna.tabaszewska@uj.edu.pl 
walki z ową pokusą - bo całkowicie wyeliminować się jej nie da - może być poszukiwanie w polskiej literaturze kolejnych powrotów i powtórzeń. Takie spojrzenie, zwłaszcza na poezję, jest o tyle uzasadnione, że po krótkim okresie deklaratywnego szukania 'nowych' problemów i ‘nowych' języków mówienia o nich, polska literatura powraca do problemów bez wątpienia starych. Każdy taki powrót to próba powiedzenia czegoś jeszcze raz, dopowiedzenia lub przeformułowania rzeczy, które zostały już powiedziane i napisane. Nie jest to więc najczęściej mówienie czegoś nowego, niemniej jest to mówienie ponownie.

W tym artykule chcę zająć się pisarzem, dla którego twórczości powtórzenia i powroty stanowią niezwykle istotny budulec tekstowego świata. Jest nim Eugeniusz Tkaczyszyn-Dycki, poeta ciągłych powrotów do przeszłości, do tych samych zwrotów, fraz i odniesień. Twórczość Dyckiego zasługuje moim zdaniem na uwagę z kilku różnych powodów. Za najważniejsze można uznać trzy: specyficzny, opierający się na powtórzeniach oraz zapętleniach język, silne, afektywne zaangażowanie podmiotu oraz unikalną zdolność do zawierania przeszłości i pamięci o niej w na wskroś współczesnych obrazach. Twórczość Tkaczyszyna-Dyckiego, przez krytyków zauważana, ale wciąż traktowana jako raczej peryferyjna, zasługuje na to, by spojrzeć na nią tak, jak sam poeta patrzy na przeszłość: ponownie, szukając w niej niekoniecznie tego, co nowatorskie, ale tego, co warte zapamiętania i przetrwania.

Pod tym względem twórczość Dyckiego domaga się - jako cennego kontekstu interpretacyjnego - przywołania koncepcji ariergardy oraz 'nieoryginalnego geniuszu' Marjorie Perloff. Amerykańska badaczka podkreślała w nich, że genialność utworu oraz jego potencjał na wywieranie późniejszego wpływu na literaturę nie ma zbyt wiele wspólnego z oryginalnością rozumianą jako 'nowość. Więlkszość uznawanych za nowatorskie utworów, chociażby autorstwa T.S. Eliota czy Ezry Pounda, jest głęboko zakorzeniona w tradycji, przez co stanowią one nie tyle awangardę sztuki, ile jej ariergardę.

Poezja Tkaczyszyna-Dyckiego jest w proponowanym przez Perloff sensie podwójnie 'nieoryginalna' - czerpie nie tylko z tradycji i z utrwalonych w jej ramach form ekspresji, lecz także z pamięci podmiotu piszącego, który za pomocą wierszy utrwala oraz powtarza nie tylko określone doświadczenia, ale i sam akt ich przypominana oraz zapisywania. Twórczość Dyckiego ma

3 Por. M. Perloff Unoriginal Genius: Poetry by Other Means in the New Century, The University of Chicago Press, Chicago 2010 oraz M. Perloff, The Futurist Moment. Avant-Garde, Avant-Guerre, and the Language of Rupture, The University of Chicago Press, Chicago and London 1986. 
więc - na podobieństwo ariergardy - zabezpieczać przed zapomnieniem to, co jeszcze pozostało możliwe do pamiętania.

\section{Elementarna narracja i'poetyka powtarzania'}

Twórczość Eugeniusza Tkaczyszyna-Dyckiego, choć sytuuje się raczej na marginesach niż w centrum zainteresowania badaczy literatury (jeśli sądzić po niezbyt wielkiej liczbie opracowań i artykułów poświęconych temu twórcy), od dawna zwracała uwagę krytyków oraz - co bardzo interesujące - innych poetów swoją specyficzną budową, opierającą się na różnych typach powtórzeń :

Natrętne powtórzenia, przestawny szyk wypowiedzi i archaiczna prostota metafor są u Tkaczyszyna-Dyckiego naturalnymi środkami, rodzącymi się z pamięci tej pierwszej lektury, zwłaszcza psalmów. ${ }^{4}$

Szukając podstawowych źródeł tak silnego wykorzystywania w poezji Tkaczyszyna-Dyckiego powtórzeń, nie sposób nie wspomnieć także o kulturze ludowej, o chłopskich przyśpiewkach, które czasem - mniej lub bardziej wprost - pobrzmiewają w jego wierszach. Utwory Dyckiego przypominają, jeśli czyta się je w ciągu, jeden po drugim, tom za tomem, wielką, ale poszatkowaną opowieść, w której wraca się do ciągle tych samych, ale - po kolejnych podejściach i powrotach - nie takich samych zdarzeń. Dla opisania tego fenomenu interesujące są uwagi Andrzeja Sosnowskiego, poety, który jest zaskakująco uważnym i przenikliwym interpretatorem wierszy innych twórców

Dycki jest poetą narracji elementarnej i złożonej refleksji. Elementarność polega na tym, że rzecz opowiadana przez poetę - w złożonych epizodach, odsłonach, odcinkach, wariantach - dzieje się w ciągłym związku z faktami narodzin i grobowej deski. ${ }^{5}$

Wiersze Dyckiego są więc równocześnie rozdrobnione, porwane i wzajemnie się zaziębiają, stale opowiadają i dopowiadają tę samą opowieść. Liczne powroty do tych samych tematów, motywów i wydarzeń przypominają

4 J. Mikołajewski Historia odrębna, w: „/esień już Panie a ja nie mam domu”. Eugeniusz Tkaczyszyn-Dycki i krytycy, red. G. Jankowicz, Ha!art, Kraków 2001, s. 6.

5 A. Sosnowski Liryzm Dyckiego, w: „/esień już Panie a ja nie mam domu”, s. 44. 
specyficzną pracę traumatycznej pamięci, która przez punktowe zwroty do istotnych momentów dąży do ich przepracowania, włączenia w szerszy kontekst opowieści o własnej tożsamości. Owe powroty nie dają jednak spodziewanego efektu, zamiast przynieść ulgę, rozwiązać konflikt lub przynajmniej uczynić go łatwiejszym dla opisu, prowadzą do kolejnych zapętleń i zacięć pamięci.

Tkaczyszyn-Dycki realizuje w swojej poezji coś, co Andrzej Skrendo określa jako 'poetykę powtarzania'. Zdaniem krytyka pod tym względem poezja Dyckiego jest bliska twórczości Tadeusza Różewicza:

Różewicz i Dycki to autorzy cierpiący na przymus powtarzania. [...] Poetyka powtórzenia Dyckiego korzysta z wynalazków Różewicza przynajmniej w tym sensie, że Dyckiemu bliska wydaje się być idea takiego pisania, żeby z poszczególnych wierszy bez troski o ich pierwotny kontekst i chronologię można było układać dowolne nowe całości podporządkowane nowej idei przewodniej. ${ }^{6}$

Podobieństwa między konstrukcją wierszy Dyckiego i Różewicza są jednak dość powierzchowne. Realizowane przez nich powtórzenia różnią się bowiem zasadniczo - jak stwierdza sam Skrendo - celem i funkcją, jaką pełnią w konstrukcji utworu. Dokonywane przez Różewicza powtórzenia przypominają raczej warstwy i elementy solidnej konstrukcji, której układ determinowany jest nadrzędnym celem stworzenia wielopoziomowej, otwartej na interpretację budowli, tymczasem Dycki przez kolejne powroty i przypomnienia czyni swą twórczość splątaną na wzór działania traumatycznej pamięci:

W efekcie, o ile Różewicz oddaje się świadome, postawangardowej robocie konstrukcyjnej, o tyle zasada generowania sensów w wierszach Dyckiego przypomina raczej mechanizm pracy marzenia sennego, odzyskiwania i przepracowywania treści wypartych, silnego libidalnego obsadzania obiektu utraconego.?

Proponowana przez badacza diagnoza wydaje się pociągająca, ale w pewien sposób niekompletna. Zauważone przez krytyka odzyskiwanie i przepracowywanie treści wypartych, które bez wątpienia wydarza się w poezji Dyckiego, nie determinuje moim zdaniem celu powtórzeń. Czy są one

\footnotetext{
6 A. Skrendo Tkaczyszyn-Dycki i Różewicz. Zarys porównania, w: Pokarmy. Szkice o twórczości Eugeniusza Tkaczyszyna-Dyckiego, WBPiCAK, Poznań 2012, s. 22-23.

7 Tamże, s. 23.
} 
sposobem na uwolnienie się od pewnego rodzaju pamięci, czy też na jej podtrzymanie? Czy mają one - jak sugeruje Anna Kałuża - wprowadzić w obieg społeczny traumę przesiedleń i wynarodowienia ${ }^{8}$ czy też odsłaniają pewną dozę niewiary w moc sprawczą języka poetyckiego?? By odpowiedzieć na pytania dotyczące celów i funkcji stosowanych przez Dyckiego powtórzeń, warto nieco głębiej je przeanalizować.

\section{Napomknięcia i dotknięcia}

Pierwsze tomy Tkaczyszyna-Dyckiego, zwłaszcza Nenia i Perygrynarz, opierają się na podobnych motywach, na powtarzalnych rozpoczęciach lub na powracających nieco na kształt uporczywych refrenów frazach. Owych powtarzalnych elementów wraz z upływem czasu już tylko przybywa. Początkowe „W moim małym domku” kontrapunktowane przez „w lubelskich domach moich przyjaciól” z Neni później zastępuje "trwoga to jest mój najlepszy dom" z Mtodzieńca o wzorowych obyczajach, następnie - „jesień już Panie, a ja nie mam domu" z Liber mortuorum, aby wreszcie dołączyło do nich powtarzające się także w najnowszych tomach „przychodzą do mnie ludzie, których dzisiaj już nie ma". W tym świecie powtarzanych fraz niewiele się zmienia: schizofrenia matki i jej wielokrotne, powracające umieranie, uporczywa, niejasna, odziedziczona pamięć oraz splątana tożsamość, zarówno narodowa, jak i seksualna, stanowią swoiste punkty orientacyjne twórczości poety.

Można moim zdaniem zaryzykować twierdzenie, że powtarzalność - realizująca się zwłaszcza na poziomie poszczególnych słów i fraz - jest próbą nadania temu splątanemu światu pewnego sensu. Skoro nie sposób uczynić tego przez uporządkowanie, zhierarchizowanie lub rozwiązanie konfliktów, czyni się to przez uporczywe powtarzanie, powracanie. Oczywiście - jak zauważa chociażby Adam Dziadek - takie postępowanie łączy ze sobą także poszczególne utwory:

Repetycje całych zwrotów czy fraz są tu tekstowymi nićmi łączącymi ze sobą kolejne utwory. Powtórzenia długich fragmentów składniowych wiążą ze sobą dwa różne i zarazem tożsame wiersze. ${ }^{10}$

8 A. Kałuża „Po obu stronach granicy”. Postacie poezji w twórczości Eugeniusza Tkaczyszyna-Dyckiego, w: Pokarmy, s. 42. Por. K. Pietrych Na granicy słowa. Transowy tok Dyckiego, w: Pokarmy, s. 133. 
W takim przypadku powtarzanie, powielanie jest najprostszym sposobem wprowadzenia jakiejkolwiek przewidywalności. Mówienie jeszcze raz o tym samym, praktycznie tymi samymi słowami nadaje nie tylko pewien porządek: jest także kompulsywnym ruchem samouspokojenia, które z czasem, w niektórych przypadkach, zaczyna coraz bardziej przypominać jąkanie się, zacięcie się podmiotu na wydarzeniu lub miejscu, o którym - nawet za pomocą powtórzeń - nie da się opowiedzieć.

To zaś oznacza, że specyficzna, naznaczona powtórzeniami i zająknięciami poezja Dyckiego domaga się odczytania uwzględniającego zarówno kontekst pracy pamięci, jak i jej cielesnego zakorzenienia. Wiersze Tkaczyszyna-Dyckiego należą - jeśliby brać pod uwagę polską poezję ostatnich dwudziestu pięciu lat - do jednych z najmocniej eksponujących związek między cielesnym, somatycznym doświadczeniem a pamięcią, traktowaną jako przedłużenie i powielenie afektywnego przeżycia. Na tę cechę poezji Dyckiego zwracał uwagę cytowany już Adam Dziadek, podkreślając, że:

Interpretowalność i czytelność tych wierszy możliwa jest wyłącznie wtedy, kiedy traktuje się je jako całość dzieła i/lub ciała..."

Punktem stale łączącym te sfery, a zarazem jednym z najbardziej eksponowanych wątków twórczości poety jest jego relacja z matką. W wierszach Dyckiego matka jest postacią funkcjonującą na przecięciu różnych światów, równocześnie je spajającą przez podważanie prostych rozgraniczeń i wydzielającą poszczególne strefy, w i wobec których orientuje się poezja Dyckiego: przeszłość i teraźniejszość, polską i ukraińską tożsamość, zdrowie i chorobę, psyche i somę, cielesność i duchowość.

Jednym z najciekawszych utworów Dyckiego dotyczących - oczywiście nie tylko - matki, jest Tumor linguae:

w sąsiednim pokoju umierała moja matka odkąd pamiętam umierała raz po raz w małym pokoju dolnym a kiedy indziej w większym górnym właśnie zaczynam w nim urzędowanie

na czym polega moje urzędowanie piszę wiersze proszę państwa pochylam się nad zmyśloną kartką

11 Tamże, s. 63. 
papieru jak nad samym sobą i spływa na mnie Natchnienie migotliwe światło zapalam je raz

po raz w ciemnym pokoju dolnym bądź górnym w zależności od rozwoju sytuacji odkąd pamiętam nie mam stosunku proszę państwa do napisanego i skończonego wiersza do widzenia moja najdroższa. ${ }^{12}$

Powtarzalne, cykliczne, trwające odkąd się pamięta umieranie matki, dokonujące się w tylko nieco zmienionych okolicznościach, jedynie pozornie odziera całe zdarzenie z przynależnego mu dramatyzmu. Umieranie zmienia się z nieodwracalnego wydarzenia w powtarzalny akt, w działanie, które nie przekracza granic świata i wyobrażenia, lecz mieści się w jego obrębie. Aktem funkcjonującym na takich samych zasadach, tak samo powtarzalnym i odartym z godności, jest u Dyckiego pisanie wierszy. W jego twórczości zachodzi więc proces, którym Adam Dziadek określa jako ekwiwalencję między ciałem a znakiem ${ }^{13}$. Powtarzalności umierania towarzyszy powtarzalność pisania o śmierci, mierzenia się z - równocześnie - wielkim tematem literackim i osobistym, traumatycznym doświadczeniem. To doświadczenie jest tyleż powtarzalne, co zawsze niedokończone, nieprzeżyte do końca, jakby mimochodem przerwane. Warto pod tym względem spojrzeć na jeszcze jeden, pochodzący z późniejszego tomu wiersz:

w sąsiednim pokoju umiera moja matka która mimo to zatrudnia się myśleniem o mnie jeszcze kiedyś napiszę na czym polega umieranie moje i jej w ciemnym pokoju dolnym. ${ }^{14}$

Umieranie staje się czynnością tak spodziewaną i zwykłą mimo swej nieodwracalności, że zmienia się w niemalże trywialną część życia. Scenerią, w której rozgrywa się umieranie matki, jest nieodmiennie ten sam dom, dom, który - paradoksalnie - jest ciągle za wielki dla podmiotu i jego matki, za

E. Tkaczyszyn-Dycki Przewodnik dla bezdomnych niezależnie od miejsca zamieszkania, w: Oddam wiersze w dobre ręce, Biuro Literackie, Wrocław 2010, s. 202. Por. A. Dziadek Styl somatyczny..., s. 58. 
wielki na to, co się w nim wydarza cyklicznie, raz na dole, raz na górze, a od czego nie ma ucieczki.

Przywiązanie Dyckiego do tak mocnych symboli współdzielonego doświadczenia może być wyjaśnione przez chęć zachowania trudnych wydarzeń w pamięci, przez próbę ich paradoksalnego przezwyciężenia za pomocą włączenia ich w sferę codzienności. Powtarzanie tych samych motywów i powracanie do nich może być w takim przypadku drogą do ich powolnego unormalnienia, do zdjęcia z nich piętna nieodwracalności i niezrozumiałości. Gest rozdrapywania po raz kolejny tych samych ran może być więc interpretowany nie tylko jako dążenie do ich utrwalenia, do uczynienia ich wiecznie żywymi, ale i przeciwnie, jako próba 'odczulenia' czułego miejsca.

Podobne odczytanie twórczości Tkaczyszyna-Dyckiego proponuje m.in. Marta Koronkiewicz, która wskazuje, że dla poety pamięć i przywiązanie do określonych zdarzeń nie jest przymusem, leczy wyborem, wyborem, który ma zniwelować konkretne zagrożenia:

Tkaczyszyn-Dycki nie może być poetą tragicznym właśnie ze względu na przywiązanie do własnych praw, na potrzebę kontroli i upewniania się; systematyczność pamiętania, która staje się odpowiedzią na skandaliczną anarchię śmierci. ${ }^{15}$

Również Piotr Śliwiński zwraca uwagę na podobne aspekty twórczości poety. Jednak ten krytyk nieco inaczej rozkłada akcenty w interpretowaniu inklinacji do powtórzeń, jakie przejawiają się w wierszach Dyckiego. Badacz, choć przyznaje, że wyjątkowa pozycja Tkaczyszyna-Dyckiego jako poety wynika wprost z jego zdolności do łączenia szaleństwa i rozumu, chaosu i porządku w materii wiersza ${ }^{16}$, dostrzega również, że nawet w tych najbardziej konstrukcyjnych momentach, przez poetycki projekt przebija autentyczny lęk:

Z drugiej strony widać, że artystyczne wyrachowanie podszyte jest psychomachią, że w kulisach poetyki rozgrywa się dramat rozumności nicowanej przez rozpacz, że tuż za ekstazą panowania nad skomplikowanym projektem poezji i egzystencji idzie lęk. ${ }^{17}$

M. Koronkiewicz Ćwiczenie pamięci, w: Pokarmy, s. 229.

Por. P. Śliwiński Wstęp. Garść intuicji, pierwsze, wciq̨ż pierwsze wrażenia, w: Pokarmy, s. 5.

Tamże, s. 7. 
Teza Śliwińskiego o nieodpartym, niemożliwym do zasłonięcia w twórczości poety lęku wydaje się prawdziwa. Tak samo jednak prawdziwe zdaje się spostrzeżenie Koronkiewicz o potrzebie panowania nad przeszłością, kontroli, która daje pewność, że nic z tego, co umarło lub ociera się o śmierć, nie zostanie bezpowrotnie stracone, bowiem zostanie w pamięci. Poezja Dyckiego przybiera przez to dość często ton podobny do litanijnego, w którym powtórzenia dają zarówno - przez swą monotonię - spokój, jak i pewność oparcia się w innej, wyższej instancji. Tą wyższą instancją w przypadku Dyckiego nie jest jednak Bóg, ani inna nadprzyrodzona istota, lecz pamięć i twórczość.

Na ten aspekt twórczości Dyckiego zwraca uwagę w swym bardzo interesującym szkicu Powtórzenia (i Napomknięcia) Alina Świeściak. Badaczka podkreśla w nim strukturalną niejednorodność pojawiających się w twórczości poety powtórzeń. Są one bowiem:

sposobem wymykania się oczywistości, ucieczką przed jednoznacznością pojęć, przed przymusami komunikacyjnymi, przed oczywistością autoprezentacji i autoreprezentacji podmiotu. ${ }^{18}$

Jak zauważa Świeściak, mimo pozornego antytradycjonalizmu Dyckiego powtórzenia, które stosuje poeta w swej twórczości, opierają się na konkretnych, tradycyjnych formach poetyckich, w tym - wzorcu lamentacyjnym ${ }^{19}$. Krytyczka podkreśla również, że powtórzenia, które stosuje Dycki, nie są i nie mogą być traktowane jako zwykłe powroty do określonych motywów. Zamiast tego, należy je traktować jako formę aktualizacji i odegrania na nowo określonych wydarzeń:

W anamnetycznym ruchu pamięci powtórzenie stanowi kolejną aktualizację tego samego. Każda anamneza, każde ponowne otwarcie znaczącego miejsca biografii-ciała poświadczone jest powtórzonym incipitem..$^{20}$

Jak powtarzające się w twórczości Tkaczyszyna frazy stanowią kolejne aktualizacje tego samego, tak również poeta aktualizuje i odtwarza we własnym losie doświadczenia, które były już wcześniej udziałem jego matki. Podmiot

\footnotetext{
18 A. Świeściak Powtórzenia (i Napomknięcia), w: Pokarmy, s. 135. 
nosi w sobie to samo rozdarcie, co matka, lecz jeszcze zmultiplikowane: po pierwsze, ze względu na fakt ich dziedziczenia, po drugie zaś, przez własną tożsamość seksualną, która czyni podmiot dodatkowo ‘obcym'. O ile bowiem matka miała kiedyś jakikolwiek punkt zakorzeniania, punkt, który został jej odebrany, ale istniał, przechował się w mniej lub bardziej wyraźny sposób w jej pamięci, o tyle podmiot w żadnym momencie go nie posiadał. Nie była nim ani tożsamość narodowa, ani akceptowalna społecznie rola, jaką dla matki była rola żony i matki właśnie.

Jedynym punktem zakorzeniania dla podmiotu może być więc jedynie matka: to w relacji z nią może odgrywać narzucane przez społeczeństwo role i to jej pamięć, rozdwojona oraz zburzona przez chorobę, może być punktem zaczepienia. Ciężko jednak o bardziej niestabilny punkt wyjścia dla budowy własnej tożsamości niż tożsamość chorej na schizofrenię osoby o splątanej przeszłości:

moja matka piękny krzew dwulicowy

jest pół Polką pół Ukrainką

raz jest miłością a raz nienawiścią

piękny krzew o dwu twarzach

moja matka śpiewa kiedy przyjadę do domu

i gdy się ją zwiąże jeszcze nie ma Polski

jeszcze nie ma Ukrainy piękny krzew o dwu

twarzach trupich który się boi siebie. ${ }^{21}$

Stosowana przez Dyckiego topika biblijna jest najmocniej eksponowana właśnie w wierszach, które poświęcone są matce. Krzew dwulicowy, przywołujący bardzo silne skojarzenia z krzewem ognistym ma być dla podmiotu swoistym objawieniem, znakiem tego, czego sam nie przeżył, ale co wciąż odciska na nim wyraźne piętno. Ucieczka od wywierającej na niego wpływ przeszłości wydaje się nie tyle nawet niemożliwa, co bezsensowna: jedynym sposobem na opanowanie przeszłości, na jej oswojenie, jest pamiętanie. Stąd też tak często powracające w twórczości Dyckiego rozpoczęcie utworów, wyglądające jak swoista czarodziejska formuła, magiczne zaklęcie to nie jest tak że zapominam. Owemu zaklęciu często towarzyszy kolejne, brzmiące

21 E. Tkaczyszyn-Dycki Młodzieniec o wzorowych obyczajach, w: Oddam wiersze w dobre ręce, s. 133. 
już jednak o wiele poważniej, groźniej: przychodza do mnie ludzie których dzisiaj jużnie ma.

Przeszłość odgrywa się więc w twórczości Dyckiego ciągle na nowo, na kształt afektywnej pamięci, raz po raz aktualizując nowe sensy i znaczenia. Jej kolejne powtórzenia przypominają następujące po sobie próby dotykania tych samych wydarzeń, wydarzeń, których nie sposób raz na zawsze opisać, o których można jedynie napomykać i nieśmiało się do nich zbliżać. To wydarzenia, których nie da się - nawet tak usilną, jak w przypadku twórczości poety - pracą pamięci domknąć, ale których można za pomocą języka literackiego dotknąć.

\section{Zależności}

Kolejne napomknienia i dotknięcia, odnoszące się do wciąż jeszcze otwartej przeszłości, rysują dość wyraźną sieć poetyckich i pamięciowych zależności Eugeniusza Tkaczyszyna-Dyckiego. Twórczość Dyckiego z upływem czasu staje się przez to coraz bardziej złożona i interesująca. Szczególne miejsce w historii poetyckich powrotów i zapętleń zajmuje Piosenka o zależnościach i uzależnianiach. Tom ten, składający się z następujących po sobie, w większości pozbawionych tytułów, jedynie ponumerowanych wierszy to - jak w dość jasny sposób wskazuje tytuł zbioru - przejmująca w swej czasem monotonnej formie historia różnego rodzaju zależności, $w$ które uwikłany jest podmiot. Gdyby starać się wymienić dwie najważniejsze zależności i zarazem uzależnienia podmiotu, byłyby to - ponownie i niezmiennie - przeszłość i matka, wzajemnie na siebie wpływające.

Matka, funkcjonująca na granicy między przeszłością a teraźniejszością, która nawet w momentach, gdy po prostu jest i to w sposób dotkliwy dla swojego otoczenia, jest zawsze również znakiem czegoś innego, swoistej nieminionej przeszłości. Owa niezakończona, wciąż wydarzająca się przeszłość powraca do podmiotu na różne sposoby, często przywoływana za pomocą wzmiankowanej już frazy 'przychodzą do mnie ludzie, których dzisiaj już nie ma':

V. przychodzą do mnie ludzie których dzisiaj już nie ma (Jasiejo, Jasiunio i Jasieczko) pewnie dlatego spotykam się z nimi bo bez nich 
nie byłoby Dycia to fakt

ogólnie znany choć z chorobą

mojej matki nikt się

nie równał nawet po denaturacie... ${ }^{22}$

To, co nie istnieje, co nie zachowało swojego trwania w teraźniejszości, stanowi w poezji Dyckiego stałą podstawę aktualnego doświadczenia. Jego specyfikę dobrze opisują koncepcje wywodzące się z badań nad postpamięcią, akcentujące wpływ dziedziczonych wspomnień na budowanie przez kolejne pokolenia własnej tożsamości. Nie sposób jednak oprzeć się wrażeniu, że mało zauważanym, ale istotnym patronem takiego stawiania pytań dotyczących przeszłości, istnienia i nieistnienia na podmiot jest także Bolesław Leśmian, a za jego pośrednictwem - również Henri Bergson. Teraźniejszość i aktualne istnienie opiera się u Dyckiego na przeszłości i pamięci o tym, co minione, w taki sam sposób, jak aktualnie bytujący świat opierał się na tym, co jedynie potencjalne lub stanowi ślad istnienia u Leśmiana.

Ludzie, których dziś już nie ma, tworzą w poezji Dyckiego tożsamość podmiotu nie mimo że ich już nie ma, ale właśnie dlatego, że ich już nie ma. Są śladem świata, który istnieje przez nich i za ich pośrednictwem. Podobnie funkcjonuje również niespójna, nie do końca należąca do rzeczywistości matka, której niepełna i splątana obecność jest przez to jeszcze dotkliwsza. Doświadczana zawsze mniej lub bardziej za jej pośrednictwem przeszłość jest podwójnie rozdarta: przez cudzą, naznaczoną chorobą pamięć, stanowiącą tylko odległy ślad przeszłości i przez wyraźny rozdźwięk między narodową pamięcią Polaków i Ukraińców. Ów rozdźwięk, zauważany i sygnalizowany przez matkę, jest powtarzany także przez Dyckiego, niemogącego i niechcącego w żaden definitywny sposób się określić, zarówno jeśli chodzi o tożsamość narodową, jak i - co w przypadku tego poety w dość specyficzny sposób połączone - seksualną.

Niezwykle interesującym zapisem owego głębokiego, wielopoziomowego rozdwojenia są dwa sąsiadujące ze sobą w tomie utwory, zaczynające się od tego samego fragmentu 'żyjemy tak płytko'. Warto przytoczyć otwierające oba wiersze wersy:

XXIV.

żyjemy tak płytko że nie możemy napisać

autobiograficznej powieści natomiast dziennik

E. Tkaczyszyn-Dycki Piosenka o zależnościach i uzależnieniach, s. 9. 
prowadzimy starannie z dbałością

o najmniejszy bodaj kamyk... ${ }^{23}$

XXV.

żyjemy tak płytko że nie możemy napisać

powieści natomiast prowadzimy dziennik

choć po latach trudno nam uwierzyć w imiona

chłopców z których każdy gdzieś się wyłachał. ${ }^{24}$

Wersy następujące po pierwszej, powtarzającej się frazie, są od siebie skrajnie odmienne, choć - gdyby zupełnie zlekceważyć stylistykę utworów - w gruncie rzeczy traktują o tym samym. Niemożliwość napisania powieści to nic innego niż skrajna niezdolność do ujęcia życia w określone ramy, do opisania go, jak należy, z początkiem i końcem, z uwzględnieniem określonych kategorii, a zwłaszcza - upływu czasu. W dzienniku każdy zapis dzieje się dziś, w nieoznaczonym, niepodlegającym uporządkowaniu teraz, a zarazem od razu, w niemożliwym do określenia momencie, staje się już tylko śladem minionego. Powieść, wymagająca perspektywy czasowej, która nadaje jej głębi, wymaga nie tylko przeżycia pewnych wydarzeń, ale także zdolności do ich refleksyjnego opracowania, jakie może umożliwić tylko czasowy i emocjonalny dystans.

Warunkiem dystansu jest opanowanie dwóch sztuk, których podmiot wierszy Dyckiego opanować nie chce: porządkowania pamięci i zapominania. Zamiast nich w wierszach poety realizowana jest konsekwentnie poetyka powtarzania, zestawiania i powracania do ciągle odgrywającej się na nowo przeszłości:

IX.

to nie jest tak że zapominam

choć nieczęsto wyprawiam się w przemyskie

przychodzą do mnie ludzie których

dzisiaj już nie ma np. siostry Serotyńskie

ostatnimi czasy nie wyprawiam się równie

chętnie w przemyskie ale to nie jest tak

\footnotetext{
23 Tamże, s. 28.

24 Tamże, s. 27.
} 
że zapominam o Argasińskich Zabrońskich

o których musiałem w końcu napomknąć

istotą poezji jest nie tyle zasadność

co bezzasadność napomknień i powtórzeń ${ }^{25}$

Sieć zależności, budowana przez obowiązek pamiętania i powtarzania, ciągłego wyliczania specyficznie pojętych 'składników' pamięci i tożsamości jest odpowiedzią na konieczność zachowania jakiejkolwiek tożsamości. Z powtarzania, z kolejnych napomknięć, ze skazanych na niepowodzenie prób odegrania przeszłości jeszcze raz, rodzi się przynależność: jeśli nie do określonej narodowości, jeśli nawet nie do przeszłości, to na pewno do określonej wizji pamięci.

\section{Przynależności}

Przemiana zależności w przynależność dokonuje się w poezji Eugeniusza Tkaczyszyna-Dyckiego stopniowo. Tom, który wyraźnie ową przemianę zaznacza, a zarazem jest jednym z najciekawszych zbiorów poety, to niedawno opublikowana Kochanka Norwida. Zbiór ten sprawia wrażenie bardziej skończonego i dopracowanego niż wcześniejsze wydania wierszy poety. Wrażenie to wynika po części z silniejszego niż zwykle zarysowania tematu przewodniego, którym w tym przypadku jest matka i jej skomplikowana historia.

Oczywiście w przypadku twórczości Tkaczyszyna matka nie reprezentuje tylko i wyłącznie postaci biologicznej rodzicielki, jest zawsze reprezentacją tego, z czego się pochodzi, znakiem kształtującej tożsamość przynależności. Niezwykle interesujący jest pod tym względem wiersz otwierający tom, zatytułowany Piosenka o deportacjach:

obudziłem się w nocy i odkryłem

prawdę której nie chciałem

przyjąć: to nie są moje wiersze

choć zdążyłem się zakraść

do szkolnych podręczników i zestarzeć

to nie jest moje miejsce

Tamże, s. 13. 
moje miejsce jest w Wólce Krowickiej

i w sąsiedniej Borowej Górze

skąd deportowano matkę na sowiecką

Ukrainę, lecz uciekła z transportu ${ }^{\mathbf{2 6}}$

Podstawowym odczuciem, któremu daje wyraz podmiot wiersza, jest doświadczenie obcości i oddzielenia. Miejsce, w którym się znajduje, jest nie jego, tak samo nie jego są wszystkie osiągnięcia. Teraźniejszość jest skrajnie nierzeczywista, jakby oszukana lub skradziona komuś innemu, kto miałby rzeczywiste prawo zakraść się do podręczników. Tymczasem bohater wiersza znajduje się nie w tym miejscu i nie w tym czasie, w którym powinien. Jego osobista historia nosi bliżej nieokreśloną zmazę fałszywości, sztuczności, jakby była dopisanym naprędce zakończeniem historii, która powinna prowadzić do zupełnie innego finału.

Wiersze Tkaczyszyna, zwłaszcza te z późniejszych tomów, można traktować jako specyficzną próbę powrotu do miejsca, w którym osobista historia zaczyna się zafałszowywać, odbiegać od utrwalonego i przewidzianego trybu. Tym miejscem, punktem, od którego wszystko idzie nie tak, nie w tym kierunku, w którym powinno, jest moment nie z przeszłości podmiotu, lecz chwila z historii jego matki. To chwila, w której dokonuje się jej deportacja, moment, w którym wyrywa się ją z jej środowiska, z jej współczesności. Uporczywe powroty Dyckiego do przerwanej historii matki, do jej szczątkowej, porwanej przez chorobę pamięci o tym czasie, są próbą nie tyle nawet sprostowania, co podopisywania określonych rzeczy do niezamkniętej jeszcze przeszłości. Owa przeszłość jest o tyle skomplikowana, że wyrwy w niej powstają nie tylko z powodu zmian dyktowanych wielką Historią, ale i przesunięć wynikających z osobistej, splątanej historii. Wszakże historia matki, tak jak chce ją widzieć poeta, to nie tylko historia deportacji, lecz także ucieczki z transportu, a więc próby wyzwolenia się z tego, co dyktuje los.

W kolejnym wierszu z tego samego tomu wątek ten zostaje w bardzo interesujący sposób rozbudowany. Sprzeciw i wola oporu matki wraca w nim w motywie dotyczącym określenia funkcji i celów poezji:

powiedziano wszak i dowiedziono

że poezja musi się opierać 
przede wszystkim zaś musi się wymykać

zrozumieniu i pochwyceniu

niczym moja matka deportowano ją

zatem po raz drugi w 1947 roku

aby już nigdy więcej nie stanowiła

zagrożenia ale o tym znajdziesz

wiadomość w pewnym przypisie

w moim najistotniejszym wierszu. ${ }^{27}$

Nieuchwytność jest tu cechą łączącą poezję i matkę poety. Rozumiana zarówno dosłownie, jako zdolność do pozostawania na wolności, wymykania się z sytuacji, które dążą do podporządkowania człowieka określonym celom, jak i metaforycznie, jako zdolność do pozostawania na granicy zrozumienia, staje się punktem łączącym te dwie sfery: osobistej historii i związanej z nią pamięci o przeszłości oraz twórczości artystycznej. Utwór ten, dość niezwykły dla twórczości Dyckiego, eksponuje nie tylko ów łączący pamięć i twórczość punkt, lecz stanowi także - nieczęsto wyrażaną tak bardzo wprost - zachętę do czytania wierszy poety jako pewnej całości.

Wzmianka o przypisie z najistotniejszego wiersza prowokuje do szukania utworu, który ‘poeta miał na myśli'. Fakt, czy istnieje rzeczywiście ten najistotniejszy, opatrzony przypisem wiersz i czy da się go odnaleźć, pozostaje jednak drugorzędny. To nie jego znalezienie jest najważniejsze, lecz sam akt szukania i pytanie o sens tego aktu. Wyraźna wskazówka dotycząca konieczności odnalezienia innego wiersza poprzedzona jest przecież dłuższym fragmentem o opieraniu się i wymykaniu poezji przed próbami jej zrozumienia. Wydaje się więc, że ów postulowany opór albo łamany jest, albo wzmacniany zachętą do poszukiwań. By dowiedzieć się, która opcja jest bardziej prawdopodobna, warto spojrzeć jeszcze na pochodzący z tego samego tomu wiersz, zatytułowany jak cały zbiór, a więc na Kochankę Norwida:

moja matka (zamknięta

w Żurawicy, Węgorzewie,

Jarosławiu) zawsze musiała do kogoś należeć

Tamże, s. 6. 
kogoś sobie zmyśliła wyobraziła

lub ktoś został jej przedstawiony

we śnie (na podobieństwo

Norwida) ale z kim wadziła się

moja matka i w jakim języku przywitał ją ojciec

niegodziwiec który nigdy

wcześniej nie słyszał o Norwidzie. ${ }^{28}$

Przynależność wydaje się przeciwieństwem oporu i ucieczki. Jednak, jak pokazuje historia matki, owa opozycja jest sztuczna. Matka, stanowiąca zazwyczaj znak oporu, jest zarazem skrajnie zależna, poszukuje przynależności. Z jednej strony ona sama musi od kogoś zależeć, bez względu na to, czy ten, od kogo zależy, istnieje poza jej świadomością, z drugiej zaś - inni są od niej zależni, w niej i w jej wersjach przeszłości zakorzenieni. Jej choroba, równocześnie oddzielająca ją od przeszłości i zbliżająca do niej, stanowi nieodmiennie jedno z formacyjnych doświadczeń podmiotu. Wiersze Dyckiego są w owym chorobowym doświadczeniu głęboko zanurzone, tak jak są zanurzone w przeszłości, zarówno tej, która stała się udziałem uciekającej z transportu matki, jak i tej, którą bieg historii niespodziewanie przerwał.

Przeszłość, do której Dycki wraca, a która zawsze jest nierealna, bo jest albo przeszłością niedokończoną, przerwaną, albo przeszłością sztuczną, cudza, która raz na zawsze usadowiła podmiot w 'nie swoim miejscu', jest nieodmienne dotkliwa, odczuwana i odbierana również na poziomie somatycznym. Poeta wielokrotnie eksponował cielesność takiej pamięci, jak również współdzielonego doświadczenia choroby. Warto pod tym kątem spojrzeć jeszcze na jeden wiersz zatytułowany Szmaty:

otóż w innej rzeczywistości moja

matka dokonywała samookaleczeń

zrazu powierzchownych niegroźnych

lecz po kilku dniach ropiejących

dlatego potrzebowała coraz więcej

prześcieradeł by opatrywać zranienia

wkrótce w całym domu (który nie istniał

w żadnej postaci) przybyło brudnych

Tamże, s. 13. 
szmat nawet pod mym jasieczkiem

nauczyłem się z nich robić wiersze. ${ }^{29}$

Tytułowe, zakrwawione i pokryte ropą szmaty są nie tylko widomym znakiem, dowodem na coraz poważniejsze zaburzenia matki, śladem jej kolejnych prób zadawania sobie cierpienia lub odebrania życia, są także źródłem twórczości poetyckiej. Znany i często eksplorowany motyw, zgodnie z którym artystyczna aktywność powstaje z brudu, z brzydoty, z bólu, tu zostaje dodatkowo wzmocniony: to cudze doświadczenie cierpienia i choroby jest źródłem wierszy, jest ich mniej lub bardziej świadomą podstawą. Cierpienie i pamięć o nim są stałym znakiem zależności i przynależności, decydującym o specyfice twórczości Dyckiego. Kolekcjonowanie, utrwalanie i powracanie do określonych wspomnień i doświadczeń oraz próby ich opisu są działaniem, które nie mają na celu domknięcia przeszłości, ale uczynienie z niej przestrzeni zakorzenienia.

Konkretne motywy, do których w swojej poezji powraca Tkaczyszyn-Dycki, na których jego pamięć i poetycki język zapętlają się, są miejscami afektywnych powtórzeń oraz zacięć pamięci, która wciąż nie radzi sobie z tym, co równocześnie minione i wciąż żywe. Kolejne zwroty pamięci przypominają poprawianie, edytowanie wydarzeń, nie po to jednak, by zmienić ich znaczenie, lecz by uczynić je wyrażalnymi za pomocą konwencjonalnego przecież języka poezji. Jako takie ulegają spłaszczeniu, stają się coraz mniej dotkliwe. Tak rozumiane powtarzanie często przypomina jąkanie się, zacięcie na określonym temacie, które realizowane jest najczęściej po to, by pokryć nieznośną ciszę, rodzącą się z niezdolności do odpowiedniego wyartykułowania się. Rodzące się z lęku przed ową ciszą mówienie oraz powracanie do określonych motywów są sposobem na zbudowanie przynależności, na jej solidne ugruntowanie nie w tym, do czego akt mówienia nawiązuje, ale w samym ruchu powtórzenia, zagarniającego w jednym geście teraźniejszość i pamięć przeszłości. 
Abstract

\section{Justyna Tabaszewska}

THE INSTITUTE OF LITERARY RESEARCH OF THE POLISH ACADEMY OF SCIENCES (WARSAW)

Repetitions and Belonging: Eugeniusz Tkaczyszyn-Dycki's Poetry and the Question of Memory

Tabaszewska reads Eugeniusz Tkaczyszyn-Dycki's poetry alongside questions of tradition and cultural memory. She points out three main characteristics: the unique language, which draws on repetition and looping, the subject's strong affective engagement, and the poet's unique ability to convey the past and memories of the past in thoroughly contemporary images. She analyses these characteristics in the context of two theories: Marjorie Perloff's non-original avant-garde Marjorie Perloff's non-original avant-garde and the poetics of memory. Tabaszewska concludes that the concrete motifs to which Tkaczyszyn-Dycki returns in his works, and on which his memory and poetic language come to loop, are places of affective repetition and memory jamming as it remains unable to come to terms with events that have not been worked through. Successive memory turns suggest an improvement, an editing of those events - not in order to change their meaning, however, but to make them expressible through the conventional language of poetry.

\section{Keywords}

memory, poetry, repetition, tradition 